\title{
War inside the mouth
}

\author{
Suja Mathews ${ }^{1}$ and Geo V Mathew ${ }^{2}$ \\ ${ }^{I}$ Assistant Professor, School of Medical Education, M.G University, Kottayam, India \\ ${ }^{2}$ Speciality Doctor, Oral and Maxillofacial Surgery, Basildon and Thurrock University Hospitals, Basildon, \\ Essex SS16 5NL, UK
}

\begin{abstract}
Declining oral health in younger generation has led to the great awakening of using bacteriocins for maintaining good oral health and treating oral infections. In this review, we present a promising family of antimicrobial proteins, the bacteriocins. Increased attention is necessary due to their powerful but narrow killing activity, stability, low toxicity to humans, and toxicity to bacteria. They are therefore considered as 'designer drugs' that target specific bacterial pathogens. Although only a few clinical trials have been conducted till date, the results suggest the use of bacteriocins, in the treatment of oral infections including dental caries, periodontal diseases and halitosis.
\end{abstract}

Key words: Lactic acid bacteria, Bacteriocins, Streptococcus mutans, Dental caries.

\section{Introduction}

There exists a harmony among the microorganisms in the mouth. Whenever there is an alteration in homeostasis (Birgitta Lindquist. 1991; Ikeda T. et al., 1988; Shiguki Hamada and Takashi Ooshima 1975), there is the possibility of occurrence of one of the most painful bacterial infection affecting human beings, i.e. the dental infections like dental caries and periodontal diseases (Walter J Loesche, 1986). Streptococcus mutans, an indigenous bacteria of mouth, is generally accepted as the main etiological agent causing dental caries in humans ( Ikeda T, et al., 1985 ). Streptococcus sobrinus is also found to cause dental caries (Birgitta Lindquist, 1991).

Bacteriocins are biologically derived, low molecular weight proteinaceous compounds, easily degraded during digestion in human beings (Orgun banwo et al., 2003). They can be the best alternative to the antibiotics in the helpless conditions of antibiotic resistance. Antibiotics differ in their actions that even narrow spectrum antibiotics do not show any preferential effect on closely related strains. Bacteriocins produced by lactic acid bacteria are ribosomally synthesised extracellular peptides or proteins, exhibiting bacteriostatic or bacteriocidal activity against closely related bacterial strains or species. Bacteriocins produced by S.mutans are called mutacins. Although there is a biological war existing between mutacins and disease causing pathological bacteria in the mouth, many invivo studies confirm the surrender of viable salivary pathogens to mutacins/bacteriocins. Mutacins inhibit the production of dental caries and sucrose formation. It may be used as a preventive agent in the control of dental caries by mouthwashes (Ikeda T et al., 1985; Fukushima H, 1985, Hirasawa M, 1984).

Bacteriocins of Gram-positive bacteria are generally cationic, amphiphilic, membrane permeable peptides, approximately 2-6 kDa in size. Typically, the biosynthesis of bacteriocins of Gram-positive bacteria is self-regulated with specifically dedicated transport mechanisms facilitating its release. Bacteriocins of Gramnegative bacteria are large in comparison to Gram-positive bacteria and range in size from less than $10 \mathrm{kDa}$ to greater than $20 \mathrm{kDa}$. Bacteriocins of Gram-negative bacteria also differ in two functional aspects,(1)they are usually released through cell lysis and (2)they are often dependent on host regulatory pathways like SOS regulation(Riley and Wertz, 2002).

Mechanism of action of bacteriocin is as that of probiotics. They compete with pathogenic agents for adhesion sites on mucosa (Guidemonde and Salminen , 2006 , Meurman , 2005 ). They can also modify the surrounding environment by modulating the $\mathrm{pH}$ or the oxidation- reduction potential, which may compromise the ability of pathogens to become established. Finally, they may provide beneficial effects by stimulating the humoal and cellular immune response (Sanders, 2008).

\section{Classification}

Bacteriocins of lactic acid bacteria, according to the classification procedure proposed by Klaenhammer (Klaenhammer 1993) and modified by Nes et al (Nes et al 1996) are divided into four classes. Class I: Bacteriocins of this class contain post-translationally modified aminoacids and are also termed Lantibiotics. Nisin, which has a GRAS (generally regarded as safe) status, for use as a direct human food ingredient, belong to this class. Bacteriocins of this class are small, heat stable and contain unusual amino acids 
Class II: Bacteriocins are of two types. Classa contain small (30-100 aminoacids), heat stable, non-lantibiotic, Pedicin like bacteriocins, with anti-listerial effects. Class IIb contains two peptide bacteriocins.

Class III: Bacteriocins are large ( $>30$ kilodaltons), heat labile proteins.

Class IV: Bacteriocins are complex bacteriocins with glycol and lipid moieties.

\section{Dental Caries}

Dental caries is one of the most common diseases in the world, second only to the common cold (Islam et al., 2007) and can lead to pain, infection and tooth loss and in severe cases, even death. The formation of plaque on the surface of a tooth starts with attachment of S.mutans on tooth, followed by multiplication and accumulation, forming a biofilm. Fermentation of sugars from remnant food particles produce acids, which etches the enamel of teeth. Bacterial processes cause damage to the tooth structure, characterized by acid demineralization of the tooth enamel (Selwitz et al., 2007). A study by Sohn and colleagues shows the link between carbonated drinks and dental caries in children. Caries was initiated by fermentation of sugars in the drinks by S.mutans (Sohn et al., 2006). In vitro studies with yogurt containing live bacteria showed selective antimutans activity, due to the antibacterial activity or bacteriocin effect of Lactic acid bacteria in it (Petti et al., 2008 ). Studies of Peter and Margret in Iceland about bacteriocins like activity among different strains of mutans found that strains from caries active subjects were more aggressive at inhibiting other strains, than those from caries free individuals (Peter and Margret, 2012).

\section{Other applications of bacteriocins}

Lactic acid bacteria are the biological basis for the production of a great multitude of fermented foods (Lasagno et al., 2002). This bacteria helps to preserve the nutritive qualities and inhibit the growth of spoilage and pathogenic bacteria (Matilla Sandhalm et al., 1999). Production of the primary metabolite, lactic acid and resulting $\mathrm{pH}$ decrease is the main preserving factor of food fermentation. The antimicrobial compounds produced by these bacteria include organic acids, hydrogen peroxide, diacetyl and bacteriocins which play the major role in ensuring the safety and extending the shelf life of the food products. Lactobacillus species are primarily used as probiotics, but can also be used as starter cultures in various fermented foods. An advantage of bacteriocins for use as a biopreservative is that they can be easily digested in human gastrointestinal tract (Nurzila et al., 1988).

Bacteriocins are active against plant pathogens. Bacteriocins of Erwinia carotovora and Serratia plymithicum are known as carotovarins. Serracin Plymithicum resembles phage tails in structure and is induced by DNA damaging agents (Jabrane et al., 2002). Glycinicin A, produced by Xanthomonas campestris, was active against most tested Xanthomonas phytopathogenic bacterial strains (Heu et al., 2001).

Bacteriocins are explored for the treatment of juvenile acne due to their specific and potent activity against Propionibacterium acnei (Van Kraaij et al., 1999). Bacteriocins from Bacillus subtilis, named mersacidin inhibits methicillin-resistant Staphylococcus with a killing efficiency similar to vancomycin (Bierbaum et al., 1995). Topical application of bacteriocins is an alternative to antibiotics in bacterial vaginitis in women (Barber et al., 1997).

Bacteriocins are also used in veterinary medicine to treat mastitis in cows, as an alternative to antobiotics (Russel and Mantovani, 2002).

\section{Conclusion}

Bacteriocins represent a new area of research in dental medicine, where the bacterial pathogens are killed by natural products. This way, harmful side effects caused by the antibiotics and risk of development of antibiotic resistance can be avoided. Effect of bacteriocins on prevention of dental caries is aimed at decreasing the number of S. mutans, which was made possible with lactic acid bacteria, regardless of product or strain used. The existence of bacteriocins in indigenous oral microflora of humans, offer the advantage of being perfectly adapted to human oral ecosystem.

\section{References}

[1]. Birgitta Lindquist. Claes-Goran Emilson : Interactions between and within S. mutans and S. sobrinus isolated from humans harboring both species : Scand. J Dent Res 1991: 99:498-504.

[2]. Ikeda T, Kurita T, Hirasawa M. Suppression of S.sobrinus 6715 (g) in the plaques by S.mutans 32 K(c). Journal of Oral Pathology 1988;17;471-4.

[3]. Shiguki Hamada, Takashi Ooshima : Inhibitory spectrum of a bacteriocin like substance (mutacins) produced by some strains of Streptococcus mutans. J Dent Res 1975:54:140-5.

[4]. Walter J Loesche. Role of Streptococcus mutans in human dental decay Microbiological reviews 1986; 50: 353-80.

[5]. Ikeda T, Koulourides T, kurita T. Antibacterial caries effect in rats and man of a bacteriocin purified from the oral bacterium Streptococcus mutans C 3603. Archs Oral Biol 1985; 30:381-4.

[6]. Ogunbanwo S. T, Sanni A .I and Onila A.A.(2003).Characterisation of bacteriocin produced by Lactobacillus plantarum F1 and Lactobacillus brevis OGI. Afr, J Biotechnol 2(8) 219-227. 
[7]. Fukushima H.. Characterisation and Mode of action of a purified bacteriocin from the oral bacterium streptococcus mutans RM 10. Archs Oral Biol 1985:30;30:229-34.

[8]. Hirasawa M. Effect of mouth rinse containing a bacteriocin from Streptococcus mutans on plaque micro flora. J Dent Res 1984:63: 1146.

[9]. Riley M.A and Wertz J.E. Bacteriocins; evolution, ecology and application .Annu Rev Microbiol

$2002 ; 56: 117-$ 37.

[10]. Guidemonde M.,Salminen S . New methods for selecting and evaluating probiotics. Dig Liver Dis . $2006 ; 38$ (Suppl 2 );5242-7.

[11]. Meurman J.H. Probiotics :do they have a role in oral medicine and dentistry ? Eur J Oral Sci $2005 ; 113$ (3) : $188-96$.

[12]. Sanders M.E. Probiotics; definition, sources, selection and uses . Clin Infect Dis .2008; 46 Suppl 2: 558-61; discussion 5144-51 .

[13]. Klaenhammer T.R, FEMS Microbiol.Rev., 1993 ,12;39-86.

[14]. Nes I.F, Diep D B, Havarstein L.S , Brurberg M.B, . Eijsink V, Holo H, Antonie van Leeuwenhoek, 1996,70 ,113-128.

[15]. I slam B, Khan S, Khan A .2007 . Dental caries: From infection to Prevention. Med Sci Monit . 13(11): RA 196-203.

[16]. Selwitz R.H, Ismail A.I, Pitts N.B ,2007. Dental caries. Lancet . 369 (9555).

[17]. Sohn W, Burt B.A, Sowers M.R. 2006. Carbonated soft drinks and dental caries in the primary dentition, J Dent Res 85(3) :262-6.

[18]. Petti S. , Tarsitani G ,Simonetti D'arca A .Antibacterial activity of yogurt against viridans Streptococci in vitro. Arch Oral Biol 2008; 53 (10): 985-90.

[19]. Peter Holbrook W, Margret O Magnusdottir, Studies on strains of S.mutans. J of Oral Microbiology .2012 ,4 ; 10611 -DOI ;10.3402/jom. V 4iO.10611.

[20]. Lasagno M,Beoletto V, Sesma F,Raya R ,Font De Valdez G,ErasenA.(2002). Selection of bacteriocin producer strains of lactic acid bacteria from diary environment. Microbiologia 25, p37-44.

[21]. Matilla-Sandholm T,Matto J Saarela M.(1999).LAB with health claim interactions and interference with gastrointestinal flora .Int .Diary $\mathrm{J} 9$ :p 25-35.

[22]. Nurliza B, K Jan, B.L John .(1988).Appl.Environ .Microbiol. 64;4842 - 4845

[23]. Jabrane A, Sabri A, Compere P, Jacques P, Vandenberghe I, Van Beeumen J, Thonart P. Characterization of serracin P, a phagetail-like bacteriocin, and its activity against Erwinia amylovora, the fire blight pathogen. App Environ Microbiol 2002;68:5704-10

[24]. Heu S, Oh J, Kang Y, Ryu S, Cho SK et al .gly gene cloning and expression and purification of glycinecin A, a bacteriocin produced by Xanthomonas campestris pv. glyycines 8ra. Appl Environ Microbiol 2001;67:4105-10.

[25]. van Kraaji C, de Vos WM, Siezen RJ, Kuipers OP. Lantibiotics:biosynthesis,mode of action and applications. Nat Prod Rep1999; 16:575-87.

[26]. 26. Bierbaum G, Brotz H, Koller KP, Sahl HG. Cloning, sequencing and production of lantibiotic mersacidin. FEMS Microbiol Lett, 1995;127:121-6

[27]. Barbaris I.L, Pajaro M.C ,Godino S.D , Aichino C .In vitro inhibition of the growth of Gardnerella vaginalis by bacteriocins produced by strains of Pseudomonas aeruginosa .Enferm Infecc Microbiol Clin.1997:15(9):473-6.

[28]. Ryan MP, Meaney WJ, Ross RP, Hill C. Evaluation of lacticin 3147and a teat seal containing thid bacteriocin for inhibition of mastitispathojens. APPL Environ Microbiol 1988;64:2287-90 